\title{
NOTES
}

\section{A Madisonian Interpretation of the Equal Protection Doctrine}

Political philosophers and constitutional theorists have long been troubled by the problem of how to protect minority rights in a democracy without at the same time undermining majority rule.' James Madison attempted to resolve this problem by creating a republican political process that would protect minority rights. ${ }^{2}$ Central to that process was Madison's belief that minorities would receive better treatment from a large federal republic than from the individual states. ${ }^{3}$

This Note begins by defending Madison's insight that minorities are best protected by the federal government. It then explores the implications of that insight for modern equal protection analysis and for John Hart Ely's theory of judicial review. The Note attempts to show not only that the federal legislative process should in theory protect minorities, but that the process has in fact worked as Madison predicted it would. Consequently, the Note contends that judicial application of equal protection doctrines against the federal government should concern itself primarily

1. The need to protect minorities from the democratic process without undermining majority rule has been a constant concern of political philosophy. See infra note 5. James Madison sought to address that concern by arguing that the political pluralism of a large republic would itself safeguard minority rights. THE FEDERALIST No. 10 (J. Madison) (Mentor Book ed. 1961). Others have argued that judicial review is needed to secure the individual rights guaranteed in the Constitution. Id. No. 78, at 466 (A. Hamilton) (Mentor Book ed. 1961); Bork, Neutral Principles and Some First Amendment Problems, 47 IND. L.J. 1, 3 (1971) (suggesting that a purpose of constitutional theory is delineation of respective spheres of majority and minority freedom).

Recently, one scholar has even suggested that a principal function of courts should be the protection of certain minorities from the democratic process. J. ELY, DEMOCRACY AND DISTRUST 135-79 (1980). Ely develops his argument from footnote four of United States v. Carolene Prods., 304 U.S. 144, 15253 n.4 (1938). That footnote suggests that "prejudice against discrete and insular minorities may be a special condition, which tends seriously to curtail the operation of those political processes ordinarily to be relied upon to protect minorities, and which may call for a correspondingly more searching judicial inquiry." Id. at 153.

2. See THE FEDERALIST, supra note 1, No. 10, at 77-84; id. No. 51, at 320-25 (J. Madison) See also J. ELY, supra note 1 , at $79-87$ (commenting on implications of Madisonian theory for protection of minorities).

3. The Federalist, supra note 1 , Nos. 10 \& 51 (J. Madison). See also THE MIND of THE FounDER xxvii (M. Meyers ed. 1981) (referring to Madison's argument that large democracy would treat minorities better than states would as lying at "the heart of Madison's Great Republic"). 
with invoking congressional review through vigorous use of the non-delegation doctrine.

The Note goes on to criticize the expansion of equal protection analysis beyond the core area of discrimination against minorities by the states. It argues that this expansion has weakened the absolute equal protection guarantees that are needed at the state level and has contributed to the exaggerated importance currently being placed on equality as a national norm.

As a matter of constitutional law, the Note argues that it is appropriate to differentiate between the states and the federal government in equal protection analysis. This holds true whether one looks to the text, to the intent of the Framers, or to arguments of structure and relation. In addition, recent Supreme Court decisions provide some evidence that a less stringent equal protection standard is in fact being applied at the federal level. The Note shows that, at the very least, a basis exists in the case law on which a Madisonian equal protection doctrine could be built.

\section{Madison's Argument that the Federal Government Will Treat Mi- norities Better than Will the States}

A distinguishing feature of American democracy is that the federal government has generally been more protective of minority rights than have the states. ${ }^{4}$ James Madison first predicted and explained this phenomenon, even before the Constitution was adopted. ${ }^{5}$ Madison argued that fed-

4. This has been true historically and is just as true today. During the colonial period, for example, a major impetus for ratification of the Constitution came from the desire of a mercantile minority to protect itself from various attempts at debtor's relief in the state legislatures. F. MCDONALD, E PLURIBUS UNUM 199-207 (1965). Thus Madison argued that "[a] rage for paper money, for an abolition of debts, for an equal division of property, or for any other improper or wicked project, will be less apt to pervade the whole body of the Union than a particular member of it ...." THE FEDERALIST, supra note 1 , No. 10, at 84 .

After the colonial period, the federal government continued to be more protective of minority rights than were the states. This was particularly evident in the disputes over slavery that culminated in the Civil War. See P. LEWINSON, RACE, CLASS, AND PARTY 80-87 (1932) (noting state constitutional barriers directed against blacks); Scruggs, The Economic and Racial Components of Jim Crow, in KEY ISSUES IN THE AFRO-AMERICAN EXPERIENGE 70-87 (N. Huggins, M. Kilson, \& D. Fox eds. 1971) (describing Jim Crow laws).

More recently, the record built by legislators in their successful effort to extend the Voting Rights Act powerfully supports the view that many states remain less trustworthy than the federal government, particularly in the area of election law. See H.R. REP. No. 227, 97th Cong., 1st Sess. (1981). For these reasons, national organizations of black and hispanic voters sought and obtained a twentyfive year extension of the Voting Rights Act. 40 CoNG. Q. 1503-04 (1982). They believed that continued federal supervision of state and local election procedures was essential to secure minority rights.

5. THE FEDERAliST, supra note 1 , No. 10, at 77-84; id. No. 51, supra note 2, at 320-25. Madison was also the first political philosopher to argue that a large democracy would protect minorities better than a small one. THE MIND OF THE FOUNDER, supra note 3, at xxvii-xxviii. Prior to Madison, political philosophers had always argued that democracy could exist only in a small state where there was the possibility of direct popular rule. Such states, it was thought, had to be fairly homogeneous and egalitarian in order to avoid severe factionalism. R. DAHL \& E. TUFTE, SIZE AND DEMOCRACY 5- 
eralism would help solve one of the central problems of democracy: the propensity of popular governments to resolve conflicts "not according to the rules of justice and the rights of the minor party, but by the superior force of an interested and overbearing majority."

Madison thought that "[t]he latent causes of faction . . . [were] sown in the nature of man," but were aggravated by systems of government that allowed monolithic and entrenched majorities to rule. ${ }^{8}$ In his view, the states were more likely to produce such entrenched majorities than was the newly proposed federal government.' In particular, Madison identified two structural features of the federal government that he believed would hinder the creation of self-sufficient and potentially tyrannous majorities.

\section{A. Variety of Interests}

First, Madison argued that the great variety of interests in a large republic would make it harder for a permanent majority coalition to form at the national level. ${ }^{10}$ The many factions in such a coalition would have

8,11 (1973) (Madison's argument marked "historical watershed"); see ARISTOTLE, POLITICS 293 (E. Baker trans. 1952); MONTESQUIEU, 1 DE L'ESPRIT DES LOIS bk.8, at 131 (1961); PLATO, 2 LAWS, IN THE DIALOGUES OF PLATO 738, 742, 771 (E. Jowett trans. 1937); J. ROUSSEAU, DU CONTRAT SOCIAL. I, 5; II, 9-10; III, 1, 3, 4, 13 (1962). It was conceded that, because of their size, such pure democracies would generally be vulnerable to invasion and inefficacious in solving major political problems.

Madison, by arguing that a large republic would best protect minorities, rejected requirements of homogeneity, egalitarianism, and smallness. His argument laid the basis for modern representative democracy and refuted the assumptions of Plato, Aristotle, Montesquieu, Rousseau, and of the Antifederalists. R. DAHL \& E. TUFTE, supra, at 8-13. See also THE ANTIFEDERALISTS xxxix-xlviii (C. Kenyon ed. 1966) (Antifederalists argued that large democracy would not work); Adair "That Politics May be Reduced to a Science": David Hume, James Madison, and the Tenth Federalist, 20 HuNTINGTON LIBR. Q. 343 (1957) (Madison's Tenth Federalist may reflect Hume's infuence).

6. THE FEDERALIST, supra note 1 , No. 10, at 77 . This problem had characterized the colonial legislatures, see generally F. MCDONALD, supra note 4, and the democracies of the Greek City States, J. BURY \& R. MEIGGS, A HISTORY OF GREECE (4th ed. 1975). Such turbulence had been considered characteristic of democracies prior to the formation of the American Republic. R. DAHL \& E. TUFTE, supra note 5 , at 11 .

7. THE FEDERALIST, supra note 1, No. 10, at 79 . Madison argued that factionalism resulted from the fallibility of men and the diversity in their "faculties ...., from which the rights of property originate." Id. at 78. Thus "the most common and durable source of factions has been the various and unequal distribution of property." Id. at 79.

8. Id. at 81 .

9. Id. at 81-84.

10. In Madison's words,

the greater number of citizens and extent of territory which may be brought within the compass of republican than of democratic government . . . renders factious combinations less to be dreaded in the former than in the latter. The smaller the society, the fewer probably will be the distinct parties and interests composing it; the fewer the distinct parties and interests, the more frequently will a majority be found of the same party ..... Extend the sphere and you take in a greater variety of parties and interests; you make it less probable that a majority of the whole will have a common motive to invade the rights of other citizens . . . .

Id. at 83. Madison elaborated on this idea in the Fifty-first Federalist where he observed that in the federal republic of the United States . . . all authority . . . will be derived from and dependent on the society, the society itself will be broken into so many parts, interests and classes of citizens, that the rights of individuals, or of the minority, will be in little danger from 
different interests that would be likely to conflict over time. ${ }^{11}$ As Madison predicted, national leaders have, in fact, had trouble designing the compromises necessary to hold such coalitions together. ${ }^{12}$ Ultimately, the difficulty of maintaining a permanent majority coalition in Congress has proven similar to that of maintaining a large, multimember cartel.

Like such cartels, majority coalitions in Congress typically contain more members than their leaders can simultaneously satisfy. Thus, some of those members are inevitably led by their own self-interest to seek new and more promising allies. ${ }^{13}$ As a result, national coalitions are unlikely to

interested combinations of the majority ... . [Thus] [i]n the extended republic of the United States, and among the great variety of interests, parties and sects which it embraces, a coalition of the majority of the whole society could seldom take place on any other principles than those of justice and the general good....

THE FEDERALIST No. 51 , supra note 2 , at 324-25.

11. These conflicting interests help to protect minority rights by making it difficult to maintain permanent majority coalitions. Although recently some parts of the Madisonian system have come under attack, the protection that system provides for minority interests is generally acknowledged. See e.g., N. ORNSTEIN \& S. ELDER, INTEREST GROUPS, LOBBYING, AND POLICYMAKING 223-30 (1978). Several scholars have agreed with Madison, for example, that group politics, together with overlapping group memberships, does limit the threat posed by factionalism. See D. TRUMAN, THE GovERNMENTAL PROCESS (1951); see also A. BENTLEY, THE PROCESS OF GOVERNMENT (1908) (describing American politics in group terms). Compare E. SCHATTSCHNEIDER, THE SEMISOVEREIGN PEOPLE 146 (1960)(suggesting that Madisonian interest group politics protects mainly those business minorities that can afford the high cost of lobbying) with N. ORNSTEIN \& S. ELDER, supra at 228 (noting the recent marked growth and influence of public interest lobbies such as Common Cause).

Some scholars have acknowledged that interest group politics protects minorities, but have challenged the assumption that that protection is desirable. T. LOWI, THE END OF LIBERALISM 287-91 (1969); Will, The Madison Legacy, NEWSWEEK, Dec. 7, 1981, at 124. Others have asserted that the minorities best protected by the Madisonian political process are those with few members and specific material interests; broad public interest groups have a harder time succeeding. M. OLSON, THE LOGIC OF COLLECTIVE ACTION 53-65 (1965); Salisbury, An Exchange Theory of Interest Groups, MIDwEST J. POL. SCI., Feb., 1969, at 1-32.

12. The difficulty experienced even by the relatively popular Reagan Administration in maintaining its coalition of moderate Republicans, economic conservatives, and social conservatives furnishes one example. See A Coalition in Shambles, NEwSWEEK, Feb. 22, 1982, at 25; The GOP's Family Feud, NEWSWEER, March 15, 1982, at 24; The Right Vs. Jim Baker, NEWSWEEK, May 31, 1982, at 31.

The difficulty of maintaining majority coalitions in Congress is readily observable. As one scholar has noted:

The fact that the American Congress has to be managed by an extraordinary amount of pulling and hauling, maneuvering and compromising, rather than by the quiet and orderly registration of party majorities, gives rise to criticism, to proposals for party reform, and to no little bewilderment among our allies around the world . . . . The members of the majority unite to control the machinery of Congress, but on substantive matters they often break ranks. So imperfect is the mobilization of party strength that some commentators dismiss party as irrelevant to the business of legislation.

V. Key, Politics, PARTies, AND Pressure Groups 677-78 (5th ed. 1964).

13. Self-interest always leads some members in a large cartel to break away because each member tends to have a different marginal cost curve. As a result it is harder for all to agree on what price to set. As cartels become larger, the costs of monitoring members' prices also increase. This makes it hard to preserve cartel discipline. For a discussion of the difficulty of maintaining cartels, see $R$. BORK, THE ANTITRUST PARADOX 292-93 (1978); R. POSNER, ANTITRUST LAW 51-53 (1976).

Analogies from the free market theory of cartels to Madisonian political theory are particularly appropriate because both theories involve an attempt to regulate human behavior by setting selfinterest against self-interest. Prior to the Enlightenment such attention to self-interest was rare. Phi- 
harden into entrenched majority and minority blocks. Self-interest and the variety of factions in a large republic prevent any one group from monopolizing the political marketplace.

At the state level, however, the smaller number of factions facilitates the forming of entrenched majority coalitions. Just as cartels form most easily in homogenous markets with few producers, entrenched majority coalitions form most easily in homogenous legislatures with few factions. ${ }^{14}$ The more competitive or fluid the environment, the more difficult cartelization becomes. Competitive environments with large numbers of dissimilar factions quickly wear down any entrenched majorities. ${ }^{15}$

Because majority coalitions in Congress have been less stable than majority coalitions in the state legislatures, special interest groups have had more influence at the national level. Congressional leaders often need minority votes and therefore have an incentive to treat minority representatives and issues favorably. Accordingly, the national political processes are unlikely to be curtailed by any special conditions of prejudice. Indeed, by forcing congressional leaders to bid for their support, minority groups in Congress have obtained the political leverage of single-issue voters: they have extracted concessions that could never be obtained at the state level. ${ }^{16}$

losophy had originally sought to improve man's condition through education and through appeals to "noble" instincts. See generally R. UNGER, KNOWLEDGE AND POLITICS (1975).

14. Antitrust scholars have long stressed the relevance of product homogeneity, as well as the number of producers, to determinations of whether a market is likely to be competitive. Cartels are most casily formed in markets where cach manufacturer's product is similar. $R$. POSNER, supra note 13 , at $59-60$.

The same situation prevails in politics. Although the number of factions in a legislature is significant, the degree to which those factions differ from each other is significant as well. Thus even if a state legislature had as many factions as did Congress, it would still be easier to form a coalition at the state level than it would be at the national level. No state will have the variety of interest groups that can be found at the national level.

15. The analogy between economic and political monopolies has broad implications for our understanding of the problem of entrenched political majorities. Economists have long recognized that even the most successful monopolies can exist only for limited periods of time. Barriers to entry tend to break down unless monopolies are reinforced by state power. Thus the economic inefficiencies of monopolization are a short-run phenomenon. See R. POSNER, supra note 13, at 57-59; J. SCHUMPETER, CAPITALISM, SOCIALISM AND DEMOCRACY 98-100 (3d ed. 1950).

Similarly, entrenched majorities at the state level exist only in the short run. Over time, the movement of people or money between states can force local majorities to change policy. But see infra note 26. In the short run, however, an entrenched majority will often prevail.

Society attempts to deal with temporary economic monopolies through the mechanism of antitrust laws. Under a consumer welfare model, such laws work only to accelerate the natural erosion of temporary monopolies. R. BORK, supra note 13, at 311. Similarly, Madisonian politics accelerates the natural erosion of entrenched political majorities. It creates the sort of fluid, competitive environment in which entrenchment is difficult.

16. Minority interests of all kinds have benefitted from the advantages created by the structure of the federal government. The Congressional Black Caucus benefitted when that group sought to extend the Voting Rights Act; middle class farmers have also benefitted when their tobacco price supports were preserved. Groups that might be shunned at the state level have found themselves wooed in Congress. There is less likelihood of a refusal to deal at the national level by a self-sufficient majority because self-sufficient majorities are themselves less likely to form. See infra note 24 (discussing some disadvantages of interest group politics). 
The instability of congressional coalitions has thus benefitted minorities by making prejudice more costly and less likely at the federal level. ${ }^{17}$

\section{B. Organizational Costs}

A second feature of the national government that operates to protect minority rights involves the sheer numbers of people who must be brought together in a large democracy to form a popular coalition. According to Madison, these numbers should create a communication problem by making it hard for would-be oppressors "to discover their own strength and to act in unison . . .."18

As Madison foresaw, communication and organizational costs are comparatively lower for discrete and insular minorities than for large, amorphous groups: their very cohesiveness enables minorities to organize more effectively than can the "silent majority."19 As the size of a polity expands, this organizational disparity steadily increases. Thus the organizational advantage that minorities possess, even at the state level, becomes more pronounced in the federal government. ${ }^{20}$

Modern communications technology has perhaps made it easier than it was in Madison's time for a majority faction to overcome organizational costs at the federal level. ${ }^{21}$ Those same advances, however, have benefitted minorities at least as much. ${ }^{22}$ Minorities are now able to concentrate their limited resources in one or two media centers where they can obtain more attention and influence than they could have if those resources were dispersed throughout the fifty states. This ability to fight one visible battle, rather than fifty unnoticed skirmishes, strengthens the political power of minorities in our federal system.

17. Such prejudice is of special concern because it may block the normal political protections for minorities. See United States v. Carolene Prods., 304 U.S. 144, 152-53 n.4 (1938); J. ELY, supra note 1.

18. THE FEDERALIST, supra note 1, No. 10, at 83 . Madison also noted that "where there is a consciousness of unjust or dishonorable purposes communication is always checked by distrust in proportion to the number. whose concurrence is necessary." Id. at 83.

19. Indeed, the "silent majority" is silent precisely because it often cannot afford the high costs of organizing and communicating. For a detailed explanation of how discreteness and insularity benefit minorities politically by lowering organization costs, see M. OLSON, supra note 11, at 165 .

The idea of applying Olson's work on organizational costs to constitutional law was introduced and developed in a series of lectures given by Professor Bruce Ackerman at the Yale Law School during the years 1978-82. It will be discussed extensively in a forthcoming book by Professor Ackerman tentatively entitled "Constitutional Politics/Constitutional Law."

20. M. OLSON, supra note 11 , at 165 .

21. See D. BRODER, THE CHANGING OF THE GuARD 386-402 (1981). Broder notes that "[i]f there is one institution that has changed American politics since World War II . . . it is television." Id. at 386. As the nationally broadcast McCarthy and Watergate hearings demonstrated, television can galvanize a national majority in a way that was impossible in Madison's time.

22. Recently political action groups have been very successful in using modern technology to affect elections. The National Conservative Political Action Committee in particular has been successful, in part through the use of mass mailing lists. It in turn has spawned various liberal imitators. 
Madison's variety of interests argument and his organizational costs argument are, of course, interdependent. ${ }^{23}$ For example, low organizational costs for minorities in Congress would be useless if that body were dominated by a stable majority coalition. State legislatures may be so dominated and may leave little room for minorities to exploit their organizational advantage. Similarly, the instability of congressional coalitions would not help minorities much if they could not afford to organize easily. Thus, large amorphous groups, whose organizing costs are high, have been relatively unsuccessful in Congress. Taxpayer ${ }^{24}$ and women can testify to this phenomenon.

The political influence and organizational strength of minorities at the federal level together should result in better protection for minority interests in Congress than in the state legislatures. ${ }^{25}$ Indeed, the very discrete-

23. It should be noted as well that Madison offered several arguments for his position in addition to the arguments pertaining to variety of interests and organizational costs. For example, he anticipated that because Congressmen represent larger districts than state representatives and live farther away from their constituents, they would tend to acquire a new "national" perspective on the issues. See THE FEDERALIST, supra note 1, No. 10 , at 83 . Even today, Congressmen tend to become more sympathetic to minority groups as they spend more time in Washington. The Antifederalists in 1789 feared exactly such an altering of Congressmen's perspectives. C. KENYON, THE ANTIFEDERALISTS xxi-cxvi (1966).

Madison also anticipated that a large republic would be more protective of minority rights than would the states because such a republic would attract more qualified leaders to govern it. These leaders, being virtuous, would try to act for the public good and would not as willingly oppress minorities. See THE FEDERALIST, supra note 1, No. 10, at 82 . While this argument is hard to prove or disprove, it is probably true that most Americans have more confidence in the abilities of their Congressmen than of their state representatives. The greater job security and prestige that attach to serving in Congress, as compared to a state legislature, probably do tend to attract more educated, if not more virtuous, politicians. Cf. Will, Reagan's Subtraction Button, NEWSWEEK, February 15, 1982 at 96. (noting that "larger tasks may attract larger people.") But see R. DAHL, A PREFACE TO DEMOCRATIC THEORY 16-17 (1956) (denouncing this proposition as "dubious and probably false").

Finally, Madison believed that to the extent that large democracies must rely on rule by representation-rather than on direct popular rule-they would be more protective of minority rights. Direct democracy, Madison believed, led to majority tyranny in the few instances in which it had been tried. THE FEDERALIST, supra note 1 , No. 10, at 77-84.

24. See M. OLSON, supra note 11, at 165-67. Feminists may believe that women have been at such a disadvantage in the recent battles relating to abortion, which they have lost despite polls indicating popular support. Taxpayers have also been at such a disadvantage relative to interest groups on all spending bills. This situation recently caused one commentator to propose an amendment designed precisely to limit interest group politics relating to spending. Will, Power to the President, NEwsWEEK, Oct. 12, 1981, at 120. That proposal advocates an item veto for the President on appropriations matters. More than the proposed Balanced Budget Amendment, it would thereby undo some of the coalition-forming advantages that Madisonian politics provides with regard to spending.

The possibly excessive protection Madisonian politics gives to minority interests has spurred various other attempts at political reform as well. Thus, Congress has at times considered proposals for the regulation and disclosure of lobbying. N. ORNSTEIN \& S. ELDER, supra note 11, at 227. Not all the minorities that benefit from interest group politics are commonly thought to deserve the benefits they get. There are costs as well as benefits associated with Madisonian interest group politics. See supra note 11.The current political system may favor constituency interest groups more than they were favored in 1789 because of the advent of single member districts and primaries. A. CAMPBELL, P. CONVERSE, W. MILlER, \& D. STOKES, Elections AND THE POLITICAL ORDER 351-72 (1966).

25. In some ways, Madison's observation that a large republic would best protect minorities has become even more valid today because of recent reapportionment decisions. See Reynolds v. Sims, 377 
ness and insularity that render minorities vulnerable at the state level accords them power disproportionate to their numbers in the federal legislative process. ${ }^{26}$

In summary, whereas state procedure and structure reinforce the tendency of majorities to tyrannize minorities, federal procedure and structure weaken any such tendency. Thus, "[i]n the extent and proper structure of the Union . . . we have [beheld] a republican remedy for the diseases most incident to republican government."27

\section{Applying Madisonian Political Theory to Equal Protection Analysis}

Madison's argument that the federal government will be more protective of discrete and insular minorities than will the states has important implications for equal protection analysis. In particular, it suggests that

U.S. 533 (1964); Wesberry v. Sanders 376 U.S. 1 (1964); Baker v. Carr, 369 U.S. 186 (1962). These decisions have increased the simple majoritarian features of the state governments by mandating the one-man, one-vote principle. See A. BICKEL, THE SUPREME COURT AND THE IDEA OF PROGRESS 10481 (1970). As a result, state governments can no longer be designed to assure that all groups will have access to the political process. The reapportioners mechanically focus instead on the notion of each individual's equal right to vote. A. BICKEL, REFORM AND CONTINUITY 1-36 (1971).

A polity designed in accordance with simple majoritarian principles is ill-equipped to protect minorities: Voting district lines may after all be drawn so as to split up the minority vote. Moreover, the one-man, one-vote rule not only fails on its own to protect minority rights but may also impede gerrymandering beneficial to minority interests. Thus the Court may have done minorities a disservice by failing to recognize the negative implications for minority rights of simple majoritarian voting schemes. Where reapportionment is not specifically intended to increase the power of a minority group, but merely to make a state more majoritarian, it may expose minorities to the danger of always being outvoted. A. BICKEL, THE SUPREME COURT AND THE IDEA OF PROGRESS 168-69 (1970); see A. BICKEL, POLITICS AND THE WARREN COURT 175-98 (1965). But see Note, Affirmative Action and Electoral Reform, 90 YALE L.J. 1811 (1981) (suggesting that malapportionment to protect minorities is less desirable than such electoral reforms as proportional representation).

26. Supporters of decentralization have at times countered this argument by maintaining that minorities will be better protected in the absence of a national government since they would then be able to "vote with their feet" by moving to sympathetic states. According to this theory, Madison's national government would be potentially more threatening to minorities than the state governments since unjust federal laws may be enforced nationwide. A repressive national government could eliminate the option minorities now have of moving to more desirable jurisdictions.

This argument ignores, however, the essence of Madison's insight. If the states are for structural reasons inherently likely to repress minorities, then it is possible that most, if not all, the states will have repressive laws respecting certain minority groups. If that proves true, then minorities will be unable to move so as to avoid majority tyranny. At any given time, Madisonianism predicts that the federal government will be more protective of minority rights than most states.

The Madisonian argument for nationalism applies only to discrete and insular minorities, however. Large amorphous groups may actually be disadvantaged by the federal legislative process. See supra note 24. For those groups decentralization may be desirable.

All this may suggest some possible divisions of authority between the states and the national government. Perhaps Congress and the federal courts should take principal responsibility for constitutionally protected minorities, while the states should assume greater responsibility for other matters. One great advantage of a federal system of government is that it allows each level of government to perform those tasks for which it is structurally best equipped. Perhaps Madison's insights on the federal structure in America will prove to be of global importance given the increased strength of many separatist movements and the increased need for supra-national coalitions. See generally A. LIJPHART, THE POLITICS OF ACCOMMODATION (2d ed. 1975) (discussing theory of consociational democracy).

27. THE FeDERalist, supra note 1, No. 10 , at 84 . 
different equal protection approaches may be appropriate at the state and federal levels. At each level, doctrines are needed that reflect the relative likelihood of invidious discrimination. In particular, a less stringent equal protection approach is called for at the federal level.

\section{A. Federal Equal Protection}

There are at least two ways of revising federal equal protection doctrine to take account of the Madisonian argument. A less stringent standard of equal protection review could be applied to federal legislation. Alternatively courts could examine the governmental procedures that created a challenged classification.

\section{Reduction to Middle Level Review}

Federal equal protection could track the theory underlying the Supreme Court's approach to gender classifications. In that area, a relaxed standard of review is currently applied. ${ }^{28}$ John Hart Ely has justified that standard on the theory that women, because of their numbers and position in society, are better able than minorities to exert political influence. ${ }^{29}$ Under Madisonian theory, the opportunities for all minority groups to exert political influence are greater at the federal than at the state level. The justification for a relaxed scrutiny of gender classifications would thus also support relaxed scrutiny at the federal level of all classifications involving

28. L. TRIBE, AMERICAN CONSTITUTIONAL LAW 1060-77 (1978); see Craig v. Boren, 429 U.S. 190 (1976); Stanton v. Stanton, 421 U.S. 7 (1975); Weinberger v. Wiesenfeld, 420 U.S. 636 (1975); Fronticro v. Richardson, 411 U.S. 677 (1973); Stanley v. Illinois, 405 U.S. 645, 651 (1972); Reed v. Reed, 404 U.S. 71 (1971).

For a general discussion of the suspect classification doctrine, see L. TRIBE, supra, at 991-1082 (providing overview of equal protection analysis and of the process by which suspect classes are identified). For a discussion of strict scrutiny specifically, see J. ELY, supra note 1, at 101-36, 148-49; L. TRIBE, supra, at 1000-02; Gunther, The Supreme Court, 1971 Term-Forward: In Search of Evolving Doctrine on $A$ Changing Court: $A$ Model for a Newer Equal Protection, 86 HARV. L. REV. 1,8 (1972); Karst, The Supreme Court, 1976 Term-Forward: Equal Citizenship Under the Fourteenth Amendment, 91 HARV. L. REV, 1, 22 (1977).

29. J. ELY, supra note 1, at 164-70. These factors, however, are counterbalanced by the high organizational costs that accompany large numbers and dispersal. M. OLSON, supra note 11 . Accordingly, prejudice against women may not be as easily overcome as prejudice against other disadvantaged groups. In particular, since women are not a discrete and insular minority some of the Madisonian protections at the federal level are of no benefit to them. Federal process, then, may protect women less than it protects racial minorities. See supra note 24 . If so, the standard justification for a lower level of gender review must fail.

Another justification, however, might rely on the fact that women have different characteristics as a group from the other groups safeguarded by equal protection doctrine. See J. ELY, supra note 1, at 164-70. Women are thus not directly analogous to the minorities the Fourteenth Amendment was intended to protect. They are not a minority that faces peculiar disadvantages at the state level. It is interesting in this connection to note that the proposed Equal Rights Amendment would ban discrimination against women at both the state and federal level. That amendment would provide that "Equality of rights under the law shall not be denied or abridged by the United States or by any state on account of sex." 40 CONG. Q. 1585 (July 3, 1982). 
discrete and insular minorities. In both instances, the Carolene Products premise of distrust is less valid. ${ }^{30}$ Unfortunately, standards of middle level review give the courts relatively little guidance in individual cases. More precise guidelines would thus be desirable.

\section{Invoking Full Congressional Review: The Non-Delegation Doctrine}

As an alternative to middle level review, courts might inquire directly into the procedures that produced the classification at issue. Justice Stevens suggested such an approach in Hampton v. Mow Sun Wong W $^{31}$ and in Fullilove v. Klutznick. ${ }^{32}$ In Hampton, the Court struck down a Civil Service Commission regulation that prohibited the hiring of aliens. Writing for the majority, Justice Stevens cited the non-delegation doctrine ${ }^{33}$ and implied that only Congress could make decisions to discriminate.

Stevens' insistence that only Congress may make such decisions is sensible given Madison's argument about the federal legislative process. Only in Congress could minorities hope to avoid invidious discrimination by "logrolling". Courts using direct proceduralist inquiry might therefore prohibit delegation in some cases on the theory that the power to discriminate must be exercised directly by a legislative body to which minorities have real access. ${ }^{34}$

30. Footnote 4 of United States v. Carolene Prods. Co., 304 U.S. 144, 152-53 (1938), observes that prejudice may sometimes be a special condition that blocks the operation of the political process. Under Madisonian theory, such prejudice is less likely to operate at the federal level because of the structure of the federal government.

31. 426 U.S. $88,100-05$ (1976).

32. 448 U.S. 448 (1980).

33. In recent years the non-delegation doctrine has been used with increasing frequency by the courts when an area of delegated discretion comes close to a fundamental value. See Hampton v. Mow Sun Wong, 426 U.S. 88 (1976) (denying Civil Service Commission authority to discriminate against aliens); Kent v. Dulles, 357 U.S. 116 (1958) (denying Secretary of State discretionary power over passports); Watkins v. United States, 354 U.S. 178 (1957) (striking down criminal contempt conviction for refusing to answer questions of House Un-American Activities Committee). Alexander Bickel explained the rationale behind the two latter decisions by arguing that the distinction between valid and invalid delegations

must lie in the importance of the decision left to the administrator or other official. And this is a judgement that will naturally be affected by the proximity of the area of delegated discretion to a constitutional issue. The more fundamental the issue, the nearer it is to principle, the more important that it be decided in the first instance by the legislature.

A. BICKEL, THE LEAST DANGEROUS BRANCH 161 (1962). See Gewirtz, The Courts, Congress, and Executive Policy-Making: Notes on Three Doctrines, 40 LAW \& CONTEMP. PROBS. 46 (1976).

The non-delegation doctrine reached its heyday in the 1930's when broad New Deal delegations were invalidated. See Schechter Poultry Corp. v. United States, 295 U.S. 495, 529-42 (1935); Panama Ref. Co. v. Ryan, 293 U.S. 388, 414-30 (1935). More recently, Justice Rehnquist has suggested reviving the non-delegation doctrine in the context of at least one modern regulatory statute. American Textile Mfrs. Inst. v. Donovan, 452 U.S. 490, 543-48 (1981) (Rehnquist, J., dissenting).

34. Stevens laid the groundwork for an even more ambitious proceduralist inquiry in his dissent in Fullilove v. Klutznick, 448 U.S. 448, 532 (1980) (Stevens, J., dissenting). The statute at issue in Fullilove ensured, by means of a quota based on race, that certain federal contracts would go to minority-owned firms. Stevens attacked the statute not for its use of a racial quota, but for its procedural history: although operating in the teeth of a constitutional rule discouraging racial classification, 
Under this approach to federal equal protection, courts would focus on whether the legislative process has been circumvented through delegation, or whether there have been other procedural flaws that would dilute minority influence. Such flaws might include, for example, the use of legislative committees or debate rules to bury issues important to minority representatives. ${ }^{35}$ Madison did not anticipate the emergence of some of the devices that modern legislators have developed to stabilize their majority coalitions. ${ }^{36}$ Where those devices exist and appear to burden minorities courts may legitimately ask for full congressional review.

In asking for such review courts should respect Congress' institutional needs. Courts should recognize that delegation and committees are often necessary, ${ }^{37}$ and that stable majority coalitions have their uses. Only when those coalitions unfairly burden minorities should the ordeal of full legislative review be required.

A proceduralist approach to federal equal protection can be more closely tailored to Madisonian theory than can a category-based reduction to middle level review. By requiring full congressional consideration, such a proceduralist approach could ensure that the Madisonian process was actually at work. In doing this, the courts would protect minorities at the

the statute had been adopted with virtually no deliberation or debate. Id. at 549-50.

The procedural delays and scrutiny required by Stevens would necessitate the prolonged maintenance of majority coalitions, which are already difficult to form and maintain. Requiring their prolonged maintenance would make this task all the more formidable. Moreover, it would give minorities time to mobilize during which they could exploit their organizational advantage over the majority. Again, this advantage would be greatest at the federal level because of the lower communications costs faced by minority leaders. See supra pp. 1408-10.

Justice Stevens' requirement that Congress engage in extensive deliberations and build a record in support of its decisions takes him beyond the federal procedural protections contemplated by Madison. Moreover, Stevens' record building notions do not provide Congress much guidance. This Note therefore recommends only that the non-delegation doctrine be used with regard to suspect classifications at the federal level. Anything more would threaten to involve the courts in the congressional decisionmaking process itself. It must be recognized, however, that delegation occurs when committees or debate rules are used to prevent a vote of Congress on issues important to minority interests. In those cases, the delegation is to a subset of the Iegislature.

35. See G. CALABRESI, A COMMON LAW FOR THE AGE OF STATUTES 70-72 (1982) ("[C]ommittees are clearly a source of inertia and often bottle up laws and reforms that the full legislature would pass.") See also J. SUNDQUIST, POLITICS AND POLICY: THE EISENHOWER, KEN. NEDY, AND JOHNSON YEARS 506-37 (1968) (suggesting that committees are much less able to frustrate will of majority of legislature now than before 1960's); Traynor, Statutes Revolving in Common-Law Orbits, 17 CATH. U.L. REV. 401, 424-25 (1968) (suggesting that for "all the vaunted responsiveness of legislatures to the will of the people, it is no secret that legislative committees, particularly those dominated by the elder statesmen of a seniority system, tend to dilute the reliability of statutes as expression of public policy").

36. These devices have no doubt emerged because of the unexpected virulence of interest group politics. Madison probably did not anticipate the extent to which majority rule would be limited by the federal legislative process. See supra note 24.

37. See G. CALABRESI, supra note 35, at 71-72 (often majority of congressmen want a bill to be killed in committee despite what they say in public); Jaffe, An Essay on Delegation of Legislatve Power: II, 47 COLUM. L. REV. 561, 592 (1947) ("Delegation of power to administration is the dynamo of the modern social service state.") 


\section{federal level while remaining faithful to the Framers' desires. ${ }^{38}$}

The Madisonian system already protects discrete and insular minorities better than is commonly realized: there have been very few federal statutes passed in this century that invidiously discriminate on the basis of race. ${ }^{39}$ Most such discrimination at the federal level has come from the bureaucracy and not from Madison's Congress. This fact has important consequences for John Hart Ely's theory of equal protection and of judicial review.

Ely asserts that the pluralist political process has characteristically failed with regard to discrete and insular minorities ${ }^{40} \mathrm{He}$ therefore sug-

38. The recognition that the federal government is more trustworthy than the states in the area of minority rights may also have some important policy implications that should be acknowledged. For example, in the area of affirmative action Madisonian theory might indicate that such programs should be run only at the federal level. Madisonians might be suspicious of state officials making any distinction on the basis of race. There might be a presumption that federal distinctions would be less likely to be harmful to minorities' best interests than state distinctions.

That presumption, however, would extend only to those distinctions made by Congress where group pressures are most fully at work. There may after all be decisions we trust Congress to make, but not adminstrative agencies or state legislatures. Thus affirmative action programs that delegate the power to discriminate, like the one in Fullilove v. Klutznick, 448 U.S. 448, 532-54 (1980) (Stevens, J. dissenting), would not be allowed to stand. The affirmative action program at issue in Fullilove delegated to administrators the key decision as to who qualified as a beneficiary. Id. at 534-35.

A Madisonian equal protection analysis could also be important in alleviating the current overuse of the equal protection doctrine. See C. BLACK, DECISION ACCORDING TO LAW (1981); G. CALABRESI, supra note 35, at 8-15. Both authors criticize the use of equal protection analysis for problems it was not intended to solve. They suggest that such overuse weakens the doctrine in the areas it was originally designed to cover, areas where it is needed most.

39. Analysis of federal equal protection cases pertaining to race indicates that Fullilove v. Klutznick, 448 U.S. 448 (1980), involved a statutory racial classification. Other federal cases involved discriminatory classifications by government officials. See, e.g., Bolling v. Sharpe, 347 U.S. 497 (1954) (District of Columbia officials maintained segregated public schools); Korematsu v. United States, 323 U.S. 214 (1944) (military order confined persons of Japanese ancestry in concentration camps); Hirabayashi v. United States, 320 U.S. 81 (1943) (persons of Japanese ancestry required by military order to obey curfew in west coast areas during early months of World War II). Even in Fullilove the key question of determining membership in a racial group was delegated to government officials. 448 U.S. at 532-50.

Federal statutes directed against racial minorities were adopted earlier in this century to restrict immigration. But these laws were targeted at non-citizens who would obviously benefit less from the Madisonian protections in a federal Congress than minority citizens who can exercise the right to vote.

40. J. ELY, supra note 1, at 135, 152-53. Ely notes that some minorities are "barred from the pluralist's bazaar" by racial prejudice. " 'Race prejudice, in short, provides the 'majority of the whole' with that 'common motive to invade the rights of other citizens' that Madison believed improbable in a pluralistic society.' " Id. at 152-53. Ely also notes that:

Of course the pluralist model does work sometimes, and minorities can protect themselves by striking deals and stressing the ties that bind the interests of other groups to their own. But sometimes it doesn't, as the single example of how our society has treated its black minority (even after that minority had gained every official attribute of access to the process) is more than sufficient to prove. Id. at 135 .

Ely does not take into account, however, the argument made above that race prejudice will be costly and unlikely at the federal level because congressional leaders will more often need minority votes. A Madisonian would not necessarily expect, as Ely does, that prejudice will distort the federal political process. A Madisonian might, however, expect such prejudice at the state level. 
gests that the courts must intervene if those minorities are to be protected. ${ }^{41}$ In fact, however, minorities have been protected by the federal political process. Thus heightened judicial solicitude, under Ely's theory, is needed primarily when dealing with the states and with bureaucrats.

Ely misstates his case when he says that it is the pluralist political process that has failed to protect minorities. Actually it is the relative absence of political pluralism at the state level and in the bureaucracy that has created a need for judicial action. Distrust should emerge in the absence of pluralist democracy and not in its presence.

Not all the groups protected by current federal equal protection doctrine, however, can be safeguarded through direct proceduralist inquiry. As mentioned above, only discrete and insular minorities are protected by the federal legislative process. ${ }^{42}$ Thus, women and other non-insular groups may need some sort of special protection. The nature of and need for that protection will doubtless remain a source of controversy. ${ }^{43}$

\section{B. State Equal Protection}

Along with a relaxation of equal protection review of federal legislation, Madisonian theory also counsels a more stringent review of state legislation. Under present doctrine, the courts maintain that any racial classification can be justified by a compelling state interest. ${ }^{44}$ Although no state interests have yet been asserted that will survive this test, this alone does not insulate the test from criticism. For the language used by the courts suggests that a balancing of interests is appropriate. If a state is likely to overestimate the weight of its interests, this balancing approach may encourage discriminatory state actions.

41. Such intervention is to be aided by the doctrine of suspect classifications, which according to Ely "function[s] as a handmaiden of motivation analysis." J. ELY, supra note 1, at 145 . By this Ely means that the use of a suspect classification should suggest to us the presence of that prejudice that under Carolene Products curtails the operation of the political process. Ely's goal is to ban such prejudice and all other unconstitutional motivations. Id. at 135-83.

Madisonian theory suggests that if we want a handmaiden for motivation analysis we should look not only at whether a law is based on a suspect classification but also, and more importantly, at the level of government from which that law emerged. The purpose of presumptions in equal protection analysis (and of the suspect classification doctrine) is to avoid ad hoc, case-by-case determinations as to when prejudice exists. Madisonian theory also accomplishes this goal, but distributes the presumptions according to the size of the polity, as well as the identity of the group discriminated against. Such a distribution is appropriate since illicit prejudice is much more likely to be present in state legislatures than in Congress. See supra p. 1408.

42. See supra p. 1409.

43. See Trimble v. Gordon, 430 U.S. 762, 780-81 (1977) (Rehnquist, J., dissenting). Since that issue is beyond the purview of this Note, attention has thus far been focused primarily on racial minorities. There is a consensus that a primary purpose of equal protection doctrine is the protection of racial groups. See also supra note 29 (discussing the appropriateness of special constitutional protection for women).

44. See L. TRIBE, supra note 28 , at $991-1082$. 
Madisonian theory imputes to the states just such a tendency to overestimate the weight of their interests at the expense of minority groups. It might therefore be interpreted to support the abandonment of balancing language at the state level so that even the most compelling interests would not overcome our suspicion of the states when minority rights are involved. According to this view, there should be an absolute prohibition against discriminatory state laws that no governmental interest could overcome.

Charles Black has argued that a "rhetoric of absolutes" is sometimes needed in constitutional law even when a principle is not really absolute. ${ }^{45}$ This may be so in areas where it is extremely unlikely that we will ever find a competing value that will win in a balancing test. In those situations, Black would have us use absolute language to indicate our presumption that the "absolute" standard should always prevail. ${ }^{46}$ In practice, we may sometimes fail to live up to our principle, but we are more likely to succeed if we begin by believing it to be absolute.47

This advantage of absolute standards may be needed for equal protection analysis at the state level. The presumption would be that state discrimination is so often unjustified that an absolute ban is needed to keep it to a minimum. At the federal level, however, where Madison has given us reason to be less suspicious, the protections associated with absolutism may be harmful unless we really want to make equality a supreme value before which everything else must fall.

The use of absolute language would provide an effective remedy against the recalcitrance of the states in two specific ways. First, absolute lan-

45. Black, Mr. Justice Black, the Supreme Court and the Bill of Rights, HARPER's, February 1961, at 63. But cf. A. BICKEL, supra note 33, at 84-98 (suggesting that Black's enthusiasm for absolutes is misplaced).

46. Absolute language would thus be especially useful in First Amendment cases, where we place an especially high value on the freedoms protected. Justice Black always emphasized the absolute nature of the First Amendment. See also G. CALABRESI, supra note 35, at 178-81 (suggesting that Justice Black did not believe as much in absolutes as in utility of rhetoric of absolutes).

47. Charles Black has illustrated the advantages of absolutes by telling a story about two fathers: One says, "My children have an absolute right to my presence and help." The other says, "Few personal decisions call for so much delicate balancing as the process of deciding from day to day, just how much my children are to have of my presence and help, as against other claims on my time and energy." The first man, if pressed, would have to admit that he could not be with his children all the time, or help them in every imaginable way, and even that it might not be a good thing if he could. He would admit, moreover-as a logical consequence of this practical admission-that he must first define his rather vague terms, before he can make out the contours of his obligation to his children, and that this definitional process can involve some pretty delicate balancing. The second man, these admissions made, would of course have to say, "All right, you may call your obligation 'absolute' if you like, since in defining it you go through the same sort of balancing process as I do when I weigh my obligations to my children against competing claims." Nothing is left at issue. But which one would you bet on for being at home the most evenings, when the hour rolls around for the bedtime ritual?

Black, supra note 45 , at 66 . 
guage at the state level would affect public attitudes. Potential discriminators would be dissuaded from looking for "loopholes," and from overestimating the status of their interests under law. This would guard against the danger that discriminatory social practices might outdistance remedial lawsuits. Second, absolute language at the state level would affect judges' attitudes and their exercise of discretion in framing remedial orders. Judges are less likely to permit inadequate remedies for state discrimination if the Constitution is read to forbid such discrimination in absolute terms.

A notorious example of an inadequate remedy may be found in a number of the cases that followed Brown v. Board of Education. ${ }^{48}$ In those cases the "all deliberate speed" formula was maintained for far longer than most commentators considered appropriate. ${ }^{49}$ Perhaps the courts had found, sub silentio, a "compelling state interest" in avoiding riots that overcame the implementation of established constitutional rights. ${ }^{50}$ Such a perversion of justice and of the proper role of the courts might not have happened had an absolute equal protection standard been maintained at the state level.

The maintenance of an absolute equal protection standard may only be possible at one level of government at a time. Thus an absolute standard at the state level may require a lower standard for the federal government. This is the case because there are very few absolute principles that can be widely applied. The more such principles we recognize, the more occasions we will have where they conflict.

As we try to apply absolute principles to more and more cases, the likelihood of such conflicts increases. ${ }^{51}$ It is therefore not surprising that

48. After the initial decision in Brown v. Board of Educ., 347 U.S. 483 (1954) (Brown I), that separate but equal schools were inherently unequal, the Court requested further argument before ordering a remedy. In Brown v. Board of Educ, 349 U.S. 294 (1955) (Brown II), the Court decided to order desegregation "with all deliberate speed." Delay in implementing desgregation followed. See, e.g., Keyes v. School District Number One, Denver, Colorado, 396 U.S. 1215 (Brennan, Circuit Justice, 1969); Alexander v. Holmes County Board of Education, 396 U.S. 19 (1969); L. TRIBE, supra note 28, at 1032-42. The delays prompted Justice Black to observe: "I fear that this long denial of constitutional rights is due in large part to the phrase 'with all deliberate speed.' I would do away with that phrase completely." 396 U.S. 1218, 1222 (Black, Circuit Justice, 1969).

49. For a critical discussion of the "with all deliberate speed" formula, see L. TRIBE, supra note 28, at 1032-42; Carter, The Warren Court and Desegregation, in THE WARREN COURT: A GRTTGAL ANALYSIS 46.57 (R. Sayler, B. Boyer, and R. Gooding, eds. 1969); McKay, "With All Deliberate Speed": A Study of School Desegregation, 31 N.Y.U. L. REV. 991 (1956). But cf. A. BICKEL, supra note 33, at 247-54 (suggesting that gradual desegregation was essential for political reasons and was consistent with Court's powers to exercise discretion).

50. The Court's belief that it could take account of popular feeling, even at the cost of denying plaintiffs their constitutional rights, suggests that it believed there was present a compelling governmental interest in avoiding riots sufficient to outweigh those rights. Given this, the flaws of the equal protection balancing test become even more apparent. That test has done harm in addition to the sanctioning of racism in Korematsu v. United States, 323 U.S. 214 (1944).

51. For a discussion of the problems in choosing between conflicting "absolute" values, see G. 
equal protection balancing language originated in a federal case and only subsequently came to cover state equal protection cases as well. Prior to that, an absolute standard had prevailed at the state level. ${ }^{52}$ Perhaps that standard could have been more easily maintained had it not been expanded to cover the federal government. ${ }^{53}$

CAlabReSI, supra note 35, at 178-81; G. CALABRESI \& P. BOBBIT, Tragic ChOICES (1978).

Note that Madison himself doubted that absolutes could be made to work in constitutional law' if they were really absolute. In a letter to Jefferson, Madison wrote:

Supposing a bill of rights to be proper the articles which ought to compose it, admit of much discussion. I am inclined to think that absolute restrictions in cases that are doubtful, or where emergencies may overrule them, ought to be avoided. The restrictions however strongly marked on paper will never be regarded when opposed to the decided sense of the public, and after repeated violations in extraordinary cases they will lose even their ordinary efficacy. Should a Rebellion or insurrection alarm the people as well as the Government, and a suspension of the Hab. Corp. be dictated by the alarm, no written prohibitions on earth would prevent the measure. Should an army in time of peace be established in our neighborhood by Brit. or Spain, declarations on paper would have as little effect in preventing a standing force for the public safety. The best security against these evils is to remove the pretext for them.

Letter from James Madison to Thomas Jefferson (October 17, 1788) reprinted in A. MASON, THE STATES RIGHTS DEBATE, ANTIFEDERALISM AND THE CONSTITUTION 178 (1964).

If absolutes are difficult to enforce when they apply to only one level of government, as Madison argues, they will prove all that much harder to enforce against both levels. Thus, if we wish to have the advantage of absolutist rhetoric in equal protection analysis, we may have to content ourselves with having that advantage only at the state level where it is most needed.

52. Balancing language first appeared in an equal protection context in Korematsu v. United States, 323 U.S. 214 (1944), a case involving the federal government. Korematsu and Fullilove v. Klutznick, 448 U.S. 448 (1980), which also involved federal discrimination, are the only two cases in which governmental use of a suspect classification has survived strict scrutiny. From the infamous Korematsu case, non-absolute language spread to state Fourteenth Amendment equal protection cases despite the fact that the states are less trustworthy than the federal government in equal protection matters.

Charles Black has commented on this development by observing that

the most serious thing the 'new' equal protection has done is, ever so slowly, but visibly in case and comment, to change discrimination against blacks from a thing seen, in the noble 1880 opinion in Strauder v. West Virginia as being categorically forbidden, to a thing only "suspected,' though with some depth, to be sure; that is what can happen when you take a term that stands in the chain of reasoning that supported the decision in a case like Korematsu-the Japanese Exclusion case-and try to make something good of it. The kiss of death never sweetens. This deplorable change, as to anti-black discrimination, may not work results as baneful as those of which it is theoretically capable. Let us pray.

C. BLACK, supra note $38,45-46$ (footnotes omitted).

53. The difficulty of maintaining absolute equal protection standards at both levels of government has important implications for the current debate over incorporation and the Fourteenth Amendment. Compare Adamson v. California, 332 U.S. 46 (1947) (Black, J., dissenting) (suggesting that Fourteenth Amendment fully incorporates Bill of Rights) with R. BERGER, GOVERNMENT BY JUDICIARY 134-56 (1977) (suggesting that Fourteenth Amendment does not fully incorporate Bill of Rights). One effect of full incorporation is that it encourages the inappropriate analogizing of federal to state cases. Charles Black cites a chilling example of this in the context of the First Amendment. C. BLACK, STRUCTURE AND RELATIONSHIP IN CONSTITUTIONAL LAW 38-39 (1969). The analogizing of Korematsu to state equal protection cases provides yet another such example.

A single equal protection doctrine, however, has imposed other costs in addition to the erosion of the once absolute state equal protection doctrine. One such cost has been the weakening of participational values at the federal level. As Alexander Bickel has argued, every time a problem is resolved by political institutions the process of consent is strengthened. A. BICKEL, THE MORALITY OF CONSENT 8 (1975). Use of the judiciary to solve problems that Congress solves well needlessly undermines democratic values.

Another cost of the current federal equal protection doctrine has been the Court's lack of success in 
In summary, the strong language of equal protection should have been saved for discrimination at the state level where it was really needed. As Alexander Bickel wrote, "[w]ords and concepts, such as those of Due Process and Equal Protection, are only words and concepts to be sure, but they create attitudes, they tend toward a mind-set, they influence future thought and action." ${ }^{254}$

III. Constitutional Justifications for Differentiating Between the States and the Federal Government in Equal Protection Analysis

It has been suggested that a Madisonian equal protection doctrine is correct as a matter of policy. It now remains to be demonstrated that such a doctrine can be anchored in the Constitution as well. As a matter of constitutional law, it is completely appropriate to differentiate between the states and the federal government in equal protection analysis. This is the case whether consideration is given to the text, to the intent of the framers, to the case law, or to arguments of structure and relation.

\section{A. The Text}

First, as Justice Stevens noted in Hampton v. Mow Sun Wong ${ }^{55}$ the due process clause appears in both the Fifth and the Fourteenth Amendments, whereas the equal protection clause does not. ${ }^{56}$ This does tend to suggest that the primary office of the latter "differs from and is additive to, the protection guaranteed by the former."

Of course the concepts of equal protection and due process are interrelated: both reflect a concern that legislation be framed in general terms and that individuals not be singled out for unusually heavy burdens. ${ }^{58}$ But

molding a consensus as to what equal protection should mean. The range of views expressed from Rehnquist's to Michelman's is truly startling. Compare Trimble v. Gordon, 430 U.S. 762, at 777-86 (1977) (Rehnquist, J., dissenting) (equal protection forbids only classifications based on race and national origin) with Michelman, On Protecting the Poor Through the Fourteenth Amendment, 83 HARV. L. REV. 7 (1969) (equal protection clause incorporates Mr. John Rawls' theory of justice).

54. A. BICKEL, supra note 53 , at 6 .

55. 426 U.S. 88,100 n.17 (1976).

56. The Fifth Amendment provides that "No person shall be ... deprived of life, liberty, or property, without due process of law." U.S. CONST. amend. V. The Fourteenth Amendment provides that "No State shall . . . deprive any person of life, liberty, or property, without due process of law; nor deny to any person within its jurisdiction the equal protection of the laws." U.S. CONST. amend. $\mathrm{XIV}, \S 1$.

57. Hampton v. Mow Sun Wong, 426 U.S. 88, 100 n.17 (1976). But cf. Buckley v. Valeo, 424 U.S. 1, 93 (1976) (suggesting that equal protection analysis in Fifth Amendment area is same as that under Fourteenth Amendment); Bolling v. Sharpe, 347 U.S. 497 (1954) (suggesting that concepts of equal protection and due process both stem from American ideal of fairness).

58. The need for generality in legislation has been defended by many authors. See, e.g., J. ELY, supra note 1, at 73-105; F. HAYER, 1 LAW, LEGISLATION AND LIBERTY (1973); Comment, The Bounds of Legislative Specification: A Suggested Approach to the Bill of Attainder Clause, 72 Yale L. J. 330 (1962). Friedrich von Hayek, in particular, has defended general rules as being essential to the 
"[ $t]$ he 'equal protection of the laws' is a more explicit safeguard of prohibited unfairness than 'due process of law." "159 Therefore, it is unlikely the two phrases were intended to be interchangeable. ${ }^{60}$

\section{B. The Framer's Intent}

In fact, as Ely observes, the notion that "the Due Process Clause of the Fifth Amendment incorporates the Equal Protection Clause of the Fourteenth . . . is gibberish both syntactically and historically . . ." intent of the framers and ratifiers of the Fourteenth Amendment was primarily to limit the power of the states to act in the area of race..$^{62}$ They wanted to make the Constitution colorblind as far as the states were concerned, and yet to leave Congress free to run programs like the Freedman's Bureau in the south. ${ }^{63}$ Thus, the Fourteenth Amendment was written, not to impose substantive limits on government at all levels, but rather to transfer certain powers from the states to the federal government. This is not surprising given that the Civil War had been fought, in part, over questions of the states' rights against the federal government.

In light of this congressional intent, it is easier to appreciate why the Supreme Court has held on at least two occasions that the federal government has special powers under section five of the Fourteenth Amendment. ${ }^{64}$ Those powers logically belong to the federal government and not to the states because the framers of the Fourteenth Amendment trusted Congress to remedy past discrimination but did not trust the states to do so. They indicated their presumption of greater federal trustworthiness by imposing an explicit equal protection clause only on the states. Their pre-

preservation of liberty. F. HAYEK, supra, 1-72.

59. Bolling v. Sharpe, 347 U.S. 497,499 (1954). This more explicit safeguard is appropriate because of our presumption that the states are less trustworthy than the federal government with respect to minority rights.

60. In fact, Ely notes that

Congressman Bingham appears at least initially to have thought that an equal protection concept was part of the Fifth Amendment's Due Process Clause. . . . That he came during the debates to recognize that his understanding was unusual is suggested by the fact that in redrafting the Fourteenth Amendment he added an Equal Protection Clause to the Due Process Clause that had appeared in his first draft.

J. ELY, supra note 1, at 202 n.79.

61. Id. at 32. Ely does, however, locate a federal equal protection principle in the Ninth Amendment. Id. at 38. Presumably the Madisonian arguments advanced above respond in part to Ely's Ninth Amendment claim. See also Estreicher, Book Review, 56 N.Y.U. L. REV. 547, 558 (1981) (disputing Ely's discovery of federal equal protection principle in Ninth Amendment).

62. J. ELY, supra note 1, at 32-33; Karst, The Fifth Amendment's Guarantee of Equal Protection, 55 N.C.L. REV. 541 (1977); Linde, Judges, Critics, and the Realist Tradition, 82 YALE L.J. 227, 232-34 (1972); Comment, Federalism and a New Equal Protection, 24 VILL. L. Rev. 557 (1978).

63. KEY ISSUES IN THE AFRO-AMERICAN EXPERIENCE, supra note 4, at 5-25 (discussing the Freedman's Burcau and federal action in race relations).

64. Fullilove v. Klutznick, 448 U.S. 448 (1980); Katzenbach v. Morgan, 384 U.S. 641 (1966). 
sumption has been borne out, as is indicated by recent section five cases, in which the federal government has used its power to remedy past discrimination to prevent the states from oppressing blacks. ${ }^{65}$

\section{Case Law Origins of Federal Equal Protection}

A third constitutional justification for differentiating between the states and the federal government looks to the origin of the federal equal protection doctrine. That doctrine emerged in Bolling v. Sharpe, ${ }^{66}$ a case involving the segregated school system run by Congress in the District of Columbia. In that case, the federal government was behaving much like a state. ${ }^{67}$

As Justice Stevens noted in Hampton v. Mow Sun Wong, the most stringent federal equal protection standard has been applied in cases where "a federal rule is applicable to only a limited territory, such as the District of Columbia, or an insular possession . . .." In such situations, the usual Madisonian protections may be easily circumvented. Congress as a whole lacks the time to devote full attention to the everyday management of a single city or island. Hence, delegation is especially likely, either to administrative officials or to a subcommittee.

Once delegation occurs, the protections afforded by federal process are weakened. This is especially true of an area such as the District of Columbia, which is not represented in Congress. ${ }^{69}$ For years, the District

65. See supra note 64.

66. 347 U.S. 497 (1954).

67. Congress's governance of the District raises different issues and problems from its governance of the nation as a whole. G. CALABRESI, supra note 35, at 127-29, 271-74. Professor Calabresi suggests that the District of Columbia Circuit's "activism" with respect to the District may have been caused by the City's lack of home rule and by the unusual position of the House District of Columbia Committec. "That Committee . . . was disproportionately made up of southern congressmen who were about as far from representative of the population of the District as one could imagine." Id. at 127.

68. 426 U.S. 88,100 (1976).

69. It might be argued that residents of the District of Columbia or of a territory are what Ely would call "a paradigmatically powerless class politically." J. ELY, supra note 1, at 83 . Because they are disenfranchised, they are only "virtually represented" in Congress. They may therefore need more protection than other minorities at the federal level.

Nonetheless, the fate of residents of the District of Columbia is to some degree constitutionally tied "to the fate of those possessing political power." Id. at 83. The Congressional Black Caucus, for example, has consistently championed causes related to the District of Columbia. Thus, it is not surprising that the discriminatory classification at issue in Bolling was made by federal administrators and not by Congress. As noted above, Congress has passed very few discriminatory statutes. See supra pp. 1414-15.

In any event the vulnerability of the disenfranchised residents of the District of Columbia or of the territories is far greater than the vulnerability of other discrete and insular minorities. Thus even if District residents needed special constitutional protection from Congress, it would not necessarily follow that other minorities would need such protection as well. In fact, the record shows that District residents at most need protection from the federal bureaucracy. Congress has on the whole treated the District quite generously. It has provided District residents with unusually generous financial assistance and it has made serious efforts to extend them political power. Congress has passed two consti- 
was in practice governed by a subcommittee dominated by southern congressmen. ${ }^{70}$ Indeed, it was their agents, and not Congress, who kept the District's public schools segregated. ${ }^{71}$ Accordingly, the discrimination that was at issue in Bolling could have been dealt with by use of the nondelegation doctrine. There was no need instead to "incorporate" the Fourteenth Amendment into the Fifth.

Several commentators have claimed that Bolling v. Sharpe is a "noninterpretivist" opinion. ${ }^{72}$ Yet the result in that case could easily have been reached by interpreting the constitutional text. A Madisonian equal protection doctrine would have reached that result by interpretivist means. ${ }^{73}$

tutional amendments enfranchising District residents and a home rule statute as well.

Congress has been similarly generous to the other disenfranchised or vulnerable groups with which it deals. For example, the residents of the territories enjoy most of the benefits of citizenship while remaining exempt from the federal income tax. Descendants of the American Indians have recently received very generous compensation for their ancient land claims. And resident aliens have been extended access to most welfare benefits despite occasional public resentment.

Thus, on the whole, these vulnerable groups appear to be "virtually represented" in Congress now, although they may not have been so represented prior to the expansion of the franchise in the 1960's. Federal equal protection, then, may safely be restricted to the use of the non-delegation doctrine.

70. See supra note 67 .

71. See REPORT OF THE PRESIDENT'S COMMISSION ON GIVIL RIGHTS, TO SEGURE THESE RIGHTS 90-91 (1947).

72. John Hart Ely, for example, suggests that, at best, federal equal protection can be grounded in the Ninth Amendment. J. ELY, supra note 1, at 32-33.

Justice Black is reported to have been concerned that the fact that the equal protection clause only appears explicitly in the Fourteenth Amendment might suggest that Bolling was, in part, a substantive due process decision. Conversation with Professor Guido Calabresi, former law clerk to Justice Black (1982).

Black voted for the outcome in Bolling despite his well-known dislike of substantive due process. See In Re Winship, 397 U.S. 358, 378-82 (1970) (Black, J., dissenting); Griswold v. Connecticut, 381 U.S. 479, 510 (1965) (Black, J., dissenting). Black's vote for the outcome in that case resulted from his belief that desegregation could only be accomplished if similar rules appeared to apply to the federal government and the states, a reason that could not have eased his concern.

73. See supra pp. 1413-15. One significant criticism that has been directed at Ely and other process-based theorists has been that those theorists cannot anchor their visions of the ideal political process in the Constitution. As Michael Perry has observed:

Ely fails to justify the imposition of his implied-from-the-Constitution conception of democracy against the will of the branches that are constituted according to an expressed-in-the-Constitution conception of democracy. . . . I cannot see how to avoid concluding that Ely has failed to defend, against the claims of interpretivism, what he set out to defend.

Perry, Interpretivism, Freedom of Expression, and Equal Protection, 42 OHIO ST. L.J. 316-17 (1981).

The Madisonian process-based theory set forth in this Note is less vulnerable to such attack. First, it comports with the constitutional text, the intent of the Framers, and the structure and relation of various constitutional clauses. And second, it represents the political theory of the man who largely designed the Constitution. Thus a Madisonian process-based theory must necessarily be an interpretivist theory as well. This is especially true since Madison's Federalist Papers were widely read by those who ratified the Constitution. As Ely points out, interpretivists should be as concerned with the intent of those who ratified the Constitution as with the intent of the Framers. J. ELY, supra note 1, at $17-18$.

That there can be an interpretivist theory of the political process is a point that has been acknowledged by Judge Robert Bork. Bork notes, for example, that "[f]reedom for political speech could and should be inferred even if there were no first amendment." Bork, supra note 1, at 23. He observes, moreover, that "[s]peech advocating violent overthrow is . . . not 'political speech' as that term must be defined by a Madisonian system of government. It is not political speech because it violates consti- 
Current doctrine was unable to accomplish this. Interpretivists ought therefore to prefer Madisonian equal protection to the more interventionist doctrine of Bolling v. Sharpe.

\section{An Argument of Structure and Relation}

Another constitutional justification for differentiating between the states and the federal government in equal protection analysis relies on an argument of structure and relation..$^{74}$ In particular, it relies on analogies to various other constitutional provisions that support the legitimacy of a Madisonian equal protection doctrine.

\section{Analogy to the Contract Clause}

One such provision is the contract clause. ${ }^{75}$ That clause explicitly holds the states to a more stringent standard than the federal government. Whereas the states are forbidden from passing any laws impairing the obligation of contracts, the federal government is not so encumbered. ${ }^{76}$

Interestingly, the contract clause, like the equal protection clause, originally served to protect a minority from majoritarian politics at the state level. But while the equal protection clause was intended mainly to protect racial minorities, the contract clause was intended to protect businessmen and merchants. Both clauses presumably were written to apply only to the states because of some recognition that it is at the state level that majoritarian politics can be most threatening. ${ }^{77}$ Both clauses then support the Madisonian proposition that minorities need constitutional protection primarily at the state level.

\section{Alternative Arguments of Structure and Relation}

A different argument of structure and relation would suggest that the federal government should be estopped from violating the equal protection

tutional truths about processes. ..."Id. at 31.

74. See C. BLACK, STRUGTURE AND RELATIONSHIP IN CONSTITUTIONAL LAW (1969).

75. The contract clause provides that "No State shall ... pass any . . . Law impairing the Obligation of Contracts . . . U.S. CONST. art. I, $\S 10, \mathrm{cl}$. 4. Prior to the adoption of the Fourteenth Amendment, the contract clause was "perhaps the strongest single constitutional check on state legislation . . . Allied Structural Steel Co. v. Spannaus, 438 U.S. 234, 241 (1978) (Stewart, J.).

The equal protection and contract clauses are the only constitutional provisions that hold the states to a standard not imposed on the federal government. The guarantee clause and the privileges and immunities clause both impose duties on the states that are already implicitly imposed against the federal government.

76. The Framers, in addition to forbidding the states from passing laws impairing the obligation of contracts, specifically authorized the federal government to pass some such laws. The Constitution empowers Congress "[t]o establish . . . uniform Laws on the subject of Bankruptcies throughout the United States." U.S. CONST. art. I, § 8, cl. 4.

77. See supra note $4 \&$ pp. $1420-21$. 
clause by its decision to exact from the states a promise not to do the same ${ }^{78}$ Presumably, this argument would extend to the contract clause, which should then be fully operational against the federal government.

There are at least two problems with this argument from the point of view of structure and relation. First, it suggests that the Constitution can never impose a limit on the states without also limiting the federal government. Yet the states are forbidden to do several things that ought to be permitted at the national level. ${ }^{79}$ Second, it suggests that the Fifteenth Amendment contains a redundancy. ${ }^{80}$ For unlike the Fourteenth Amendment, the Fifteenth Amendment guarantees the right to vote from federal as well as state abridgement. ${ }^{81}$

The Madisonian argument of structure and relation, in contrast, avoids these pitfalls. It allows state power to be limited without limiting the federal government; in fact, it holds that this is particularly appropriate in the area of minority rights where the states are suspect. In that area, as in the area of waging war, it finds the states to be less competent than the federal government.

The Madisonian explanation for the Fifteenth Amendment follows logically from concerns of process. In other words, the federal legislative process will best protect minorities if they are guaranteed the vote. Thus

78. Charles Black and Kenneth Karst suggest that "national citizenship implies some substantial measure of equality among the nation's citizens." C. BLACK, supra note 74, at 51-61; Karst, supra note 62 , at 549 . Karst then concludes that this must be the same measure of equality that the states are required to maintain among their own residents by the equal protection clause. Karst also acknowledges two exceptions where " 'overriding national interests' might justify federal legislation even though a similar state law would fail the test of the fourteenth amendment." Karst, supra note 62, at 558. These exceptions involve situations where federalism concerns or separation of powers concerns are paramount. Id. at 558-62.

Karst is undoubtedly correct in asserting that national citizenship implies a certain measure of equality among citizens. He is less clear, however, in explaining why it should be the same measure of equality imposed on the states by the equal protection clause. As has been argued above, minorities face different problems at the state and national levels. Different presumptions regarding the likelihood of prejudice accordingly seem appropriate.

To make his argument, Karst seems to assume that the equal protection clause of the Fourteenth Amendment extended an implicit notion of equal national citizenship to the states. Id. at 552. Thus he argues that the content of the equal protection clause helps to define the principle of equal national citizenship. This, however, ignores the privileges and immunities clause. In fact, it was that clause and not the equal protection clause that declared us all to have the rights of citizens of the United States.

Karst's theory, moreover, does not explain why the Thirteenth and Fifteenth Amendments were both written to apply to the federal government, while the Fourteenth Amendment was not. A possible explanation is set forth below.

79. See U.S. CONST. art. I, §10.

80. The Fifteenth Amendment provides that "[t]he right of citizens of the United States to vote shall not be denied or abridged by the United States or by any State on account of race, color, or previous condition of servitude." U.S. CONST. amend. V, § 1. Under this theory the Thirteenth Amendment would presumably be redundant as well, since it forbids the federal government as well as the states from allowing slavery. U.S. CONST. amend. XIII, § 1.

81. Ely makes this point forcefully in his discussion of federal equal protection. J. ELY, supra note 1 , at $32-33$. 
Madison would find no anomaly in the Reconstruction Congress' decision to extend the Fifteenth Amendment to the federal government. That decision makes as much sense as the decision not so to extend the Fourteenth.

\section{The Takings Clause and the Ban on Federal Bills of Attainder}

It might be suggested that the restraints imposed on the federal government by the takings clause ${ }^{82}$ or the bill of attainder clause ${ }^{83}$ evidence a distrust of Congress comparable to Madison's distrust of the states. This argument, however, misunderstands the role of those clauses in our constitutional scheme. The takings clause and the bill of attainder clause are tailored specially to bar legislative abuse that otherwise might occur even despite federal procedural protections.

Such abuse is likely when legislation singles out individuals or very small groups not represented in the legislature. ${ }^{84}$ Individuals and small groups do not have the organizational advantage over the majority that safeguards most minorities at the federal level. ${ }^{85}$ Moreover, individuals are less likely than multi-member minorities to have sympathizers in Congress. They are therefore less able to capitalize on the instability of national legislative coalitions.

It is these individuals and very small groups that the takings clause and the bill of attainder prohibition typically safeguard. Those clauses provide the same protection for individuals at both levels of government that is provided for groups at the state level by the provisions on equal protection and obligation of contracts. At the federal level, however, groups were originally not thought to need constitutional safeguards for the reasons implied by Madisonian theory. ${ }^{86}$

82. The takings clause provides that "private property [shall not] be taken for public use, without just compensation." U.S. CONST. amend. V. The just compensation language was held to operate against the states through the due process clause of the Fourteenth Amendment in Chicago, Burlington \& Quincy Ry. v. Chicago, 166 U.S. 226, 235-41 (1897).

83. "No Bill of Attainder or ex post facto law shall be passed [by Congress]." U.S. CONST. art. I, § 9, cl. 3. Also, "No State shall . . . pass any Bill of Attainder, [or] ex post facto law . . . " U.S. CONST. art. I, $\S 10$, cl. 4.

84. See Comment, The Bounds of Legislative Specification: A Suggested Approach to the Bill of Attainder Clause, 72 YALE L.J. 330, 351 (1962) (suggesting that legislatures are unsuited to task of finding specific facts in individual situations).

85. See supra pp. 1408-10.

86. Madison himself so distrusted the states that he thought the bill of attainder clause was needed more at the state than at the federal level. As he explained:

I wish also, in revising the constitution, we may throw into that section, which interdicts the abuse of certain powers in the State Legislatures, some other provisions of equal, if not greater importance than those already made. The words, 'No State shall pass any bill of attainder, ex post facto law,' \&c. were wise and proper restrictions in the constitution. I think there is more danger of those powers being abused by the State Goverments than by the Government of the United States.

James Madison, Speech Placing the Proposed Bill-of-Rights Amendments before the House of Representatives, (June 8, 1789), reprinted in A. MASON, supra note 51, at 187. 
The existence of these clauses, then, suggests only that federal procedural protections do not guard against abuse in all circumstances. It provides no support for the proposition that those protections are not more powerful than any provided by the state legislative process. ${ }^{87}$

\section{Evidence that the Supreme Court is Differentiating Between the States and the Federal Government in Equal Protection Analysis}

One remaining question is whether, given the normative and constitutional arguments so far considered, any evidence exists to suggest that the Supreme Court might differentiate between the states and the federal government in equal protection analysis. The Court has never held explicitly that different standards are applicable. But there are indications that it has taken into account some of the concerns discussed above.

One such indication may be found in the Supreme Court's decision in Fullilove v. Klutznick. ${ }^{88}$ There the Gourt upheld Congress' power to set affirmative action quotas based on race under section five of the Fourteenth Amendment. Previously, the Court had denied similar authority to an instrumentality of the state of California in Regents of the University of California v. Bakke. ${ }^{89}$ The discrepancy between these two decisions might be explained by arguing that the Court implicitly recognized that there must be stricter equal protection review of state actions than of federal ones. Indeed, the Court noted in Bakke that it has "previously recognized the special competence of Congress to make findings with respect to the effects of identified past discrimination and its discretionary authority to take appropriate remedial measures." 90

This does not mean, though, that Madison believed a bill of attainder clause was unnecessary at the federal level. As demonstrated above, his theory does suggest that the factors that protect minority groups at the federal level do not adequately protect individuals. Special constitutional safeguards are therefore needed.

87. In addition to the takings clause and the bill of attainder prohibition, at least four other constitutional clauses also limit Congress' power to single out individuals for unusual or non-uniform treatment. Thus, the Third Amendment forbids singling out individual citizens to bear the public burden of housing soldiers. That burden can be imposed in time of war only in a manner to be prescribed by law. U.S. CONST. amend. III. Similarly, Congress is empowered to pass only uniform bankruptcy laws. It thus may not single out individual creditors or debtors for special treatment. U.S. CONST. art. I, $\$ 8$, cl. 4.

John Hart Ely has noted that the Eighth Amendment forbids singling out individual lawbreakers for unusual punishments. He notes as well that the ban on ex post facto laws makes it generally harder to burden any individual or small group: Retrospective legislation can more easily single out targeted individuals. J. ELY, supra note 1, at 73-105. The existence of so many clauses that ensure the generality of legislation indicates the importance of that principle in American constitutional law.

88. 448 U.S. 448 (1980).

89. 438 U.S. 265 (1978). See also G. CALABRESI, supra note 35, at 2.

90. Id. at $302 \mathrm{n.41}$ (1978) (emphasis added). The Court pointedly noted that it was not presented in Bakke "with an occasion to review legislation by Congress pursuant to its powers under $\$ 2$ of the Thirteenth Amendment and $\S 5$ of the Fourteenth Amendment to remedy the effects of prior discrimination." Id. 
Another area of equal protection analysis where the Court has clearly differentiated between federal and state actions is alienage. ${ }^{91}$ There the Court has in several instances applied a lower equal protection standard to the federal government than to the states. Thus, in Mathews v. Diaz, ${ }^{92}$ the Court upheld a federal medicare program conditioning aliens' eligibility on five years residence in the United States. Similarly, in Hampton v. Mow Sun Wong, the Court announced that the federal government would be held to a lower standard than the states in equal protection decisions pertaining to alienage..$^{93}$ It thus declined to extend its alienage decision in Sugarman v. Dougall ${ }^{\text {s }}$ to the federal government. In Hampton, Justice Stevens went so far as to observe that

The concept of equal justice under law is served by the Fifth Amendment's guarantee of due process, as well as by the Equal Protection Clause of the Fourteenth Amendment. Although both Amendments require the same type of analysis . .., the two protections are not always coextensive. Not only does the language of the two Amendments differ, but more importantly, there may be overriding national interests which justify selective federal legislation that would be unacceptable for an individual State. On the other hand, when a federal rule is applicable to only a limited territory, such as the District of Columbia, or an insular possession, and when there is no special national interest involved, the Due Process Clause has been construed as having the same significance as the Equal Protection Clause. ${ }^{95}$

Yet another area of equal protection law where the federal government is held to a less stringent standard than the states involves classifications pertaining to Indians. Despite the fact that few groups in American society are more discrete and insular than the American Indian, a whole title of the United States Code is filled with classifications treating Indians differently from other Americans. ${ }^{96}$ Most of these classifications were origi-

It is interesting to note in this connection that the Court first enunciated its higher constitutional intent standard in Washington v. Davis, 426 U.S. 229 (1976), a federal case. That standard has since been applied somewhat more leniently in Rogers v. Lodge, 102 S. Ct. 3272 (1982), a case decided under the Fourteenth Amendment. This result is entirely consistent with Madisonian theory. Courts should more readily infer discriminatory intent where state officials are involved.

91. G. GUNTHER, CONSTITUTIONAL LAW 897 (1980); Note, The Equal Treatment of Aliens: Preemption or Equal Protection? 31 STAN. L. REV. 1069 (1979); Note, State Burdens on Resident Aliens: A New Preemption Analysis, 89 YALE L.J. 940 (1980).

92. 426 U.S. 67 (1976).

93. 426 U.S. 88 (1976).

94. 413 U.S. 634 (1973).

95. 426 U.S. at 100. See also Comment, The Emerging Constitutional Jurisprudence of Justice Stevens, 46 U. CHI. L. REV. 155, 206-32 (1978) (explaining Justice Stevens' views on Fifth Amendment equal protection).

96. Morton v. Mancari, 417 U.S. 535, 552 (1974). The Court noted in Morton that "[1]iterally 
nally enacted to "protect" Indians from their new white neighbors. They have been upheld by the courts in part because Indian relations originally involved foreign policy questions.

Another factor influencing the courts, however, may have been the fact that many of these statutes were enacted only after going through the ordeal of full congressional review. Indeed, since the extension of the franchise, Congress has been quite generous in its treatment of Indians. ${ }^{97}$ The courts may therefore be less suspicious of recent federal classifications in this area.98

At the state level, however, different presumptions prevail. The states are strictly limited in their ability to legislate on Indian affairs both because of federal preemption and because of the equal protection clause.99 Indeed, the Court has even upheld a congressional decision to deny the state courts jurisdiction over many cases involving ordinary crimes commited by Indians. ${ }^{100}$ Those cases are tried instead in the presumably more friendly federal forum. ${ }^{101}$

There is at least one area of equal protection law, however, where no differentiation is made between federal and state classifications. That area involves classifications based on gender. ${ }^{102}$ The Court's failure to differentiate with regard to gender discrimination is completely explainable in terms of Madisonian theory. Because women are not a discrete and insular minority, they obtain no special political advantage at the federal level.

every piece of legislation dealing with Indian tribes and reservations . . . single[s] out for special treatment a constituency of tribal Indians living on or near reservations. If these laws ..., were deemed invidious racial discrimination, an entire Title of the United States Code (25 U.S.C.) would be effectively erased. . . ." Id.

97. See supra note 69.

98. It is possible that classifications that predate this expansion of the suffrage merit different treatment. Some scholars might argue that a decision by the current Congress should be necessary to keep statutes of this sort in effect. See G. CALABRESI, supra note 35.

99. Antoine v. Washington, 420 U.S. 194, 204-05 (1975); Morton v. Mancari, 417 U.S. 535, 551 (1974); McClanahan v. Arizona Tax Comm'n, 411 U.S. 164 (1973); see L. TRIBE, supra note 28, at 1016-19. The differential equal protection standard applied to Indians exists for many of the same reasons as the differential standard applied to aliens. See supra note 91.

100. United States v. Antelope, 430 U.S. 641 (1977).

101. Special jurisdictional provisions of this sort are especially intriguing in light of the current controversy over the $\S 1983$ jurisdiction of the federal courts. Section 1983 was originally passed to ensure that blacks would have access to federal courts to redress violations of their constitutional rights. In defining the relative jurisdiction of the state and federal courts, Congress has thus demonstrated a preference for giving constitutionally recognized minorities easier access to the federal court system. This makes sense given the greater sympathy federal institutions have for minority rights.

Indeed, Article III itself confers federal jurisdiction in a class of cases where one party is in danger of being tried by a "foreign" judicial system. Thus, for example, representatives of one state may not be tried in another state's courts. "Foreign" courts might be unsympathetic because the affected party would not have access to the political institutions that created the court system. Similarly Congress may simply have been concerned that blacks and Indians have reduced access to the state political institutions that create the state courts. If so, this concern may provide a limiting principle for $\$ 1983$. Federal jurisdiction should ensue only where the rights of minority groups are at issue.

102. Frontiero v. Richardson, 411 U.S. 677, 682-84 (1973). 
It is thus logical that the Court has not distinguished between federal and state gender-based classifications. Women have different problems from those of other groups safeguarded by the equal protection clause. ${ }^{103}$

Despite strong inferential support, ${ }^{104}$ one cannot explain the bulk of equal protection jurisprudence by arguing that the Supreme Court differentiates sub silentio between the states and federal government. Nevertheless, because some cases can be thus explained, it is not extravagant to say that there exists a basis in the case law on which a "Madisonian" equal protection doctrine could be built. ${ }^{105}$

\section{Conclusion}

James Madison's theory that a large federal republic would treat minorities better than the states has been argued to be essentially correct. This is the case for at least two reasons: first, the great variety of interests in a large republic makes it hard to form permanent majority coalitions, and second, majorities in such a republic face comparatively high organizational costs.

On the basis of these structural arguments, Madisonian theory counsels different equal protection standards for the review of federal and of state legislation. At the federal level, Madisonian theory would support a procedural equal protection standard that would make vigorous use of the non-delegation doctrine. At the state level, however, a more stringent, absolutist approach would be appropriate.

103. See supra note 24.

104. A final area of equal protection analysis where it has been argued that the Court has shown more deference to the federal government than to the states involves classifications based on illegitimacy. For a discussion, see Comment, Federalism and A New Equal Protection, 24 VILL. L. REV. 557 (1978).

105. Another indication that the Supreme Court is differentiating between the federal and state governments in equal protection analysis may be found in the simple fact that the Court strikes down proportionally more state laws than federal statutes. This might suggest either that there are fewer violations in fact at the federal level than at the state level, or that a lower standard of review is actually being applied, or even that some combination of both these factors is present. In any event, the outcome is consistent with the Madisonian model. 